son's disease appeared. As in previously reported cases, he underwent a series of investigations before the correct diagnosis was

1 Hildick-Smith M. Parkinson's disease: In: Pathy MSJ, ed. Principles and practice of geriatric medicine. Chichester: John Principles and practice of geriatric medic
Wiley and Sons, 1985; pp 769-78.

2 Croxson SCM, Pye IF. Dysphagia as the presenting feature Croxson SCM, Pye IF. Dysphagia as the presenting featu
in Parkinson's disease. Geriatric Med 1988; August: 16.

in Parkinson's disease. Geriatric Med 1988; August: 16. Lieberman I, Liebowitz M. Dysphagia in Parkinson's disease. Am $\mathcal{f}$ Gastroenterol 1980; 74: 157-60.

4 Stroudley J, Walsh M. Radiological assessment of dysphagia in Parkinson's disease. Br $\mathcal{Y}$ Radiol 1991; 64: 890-3. reached. This is an unusual presentation of a common disease and should be considered in all cases of unexplained dysphagia.

5 Bushmann M, Dobmeyer SM, Leeker L, Perlmutter JS. Swallowing abnormalities and their response to treatment in Swallowing abnormalities and their response to treatment in 6 Pard MR, Woodward MC, Gibson EM, Phyland DJ, Fonda D. Asymptomatic swallowing disorders in elderly patients D. Asymptomatic swallowing disorders in elderly patients
with Parkinson's disease: a description of findings on clinical examination and videofluoroscopy in sixteen patients. Age Ageing 1994; 23: 251-4.

\title{
12 February 1809
}

Charles Darwin (1809-82) was born in Shrewsbury, UK, son of a successful local doctor and grandson of Erasmus Darwin and Josiah Wedgwood. He was a medical student at Edinburgh but for two years only (1825-27) and then moved to Christ's College, Cambridge (1828) to study for the church but instead became a naturalist on HMS Beagle (1831 - 36). He married his cousin Emma Wedgwood (1839) and lived as a country gentleman at Downe, Kent. This is now a research institute of the Royal College of Surgeons. His epoch-making theory of evolution by natural selection was published as "The Origin of Species by means of Natural Selection" in November 1859. He is buried in Westminster Abbey, London, UK. 